\section{Putting flesh onto the bones}

\section{Malcolm C. McKenna}

Mammal Evolution: An Illustrated Guide. By R. J. G. Savage and M. R. Long. British Museum (Natural History)/Facts on File:1986. Pp.264. £17.50, \$35.

FOR most fossil mammals, dry bones have been brought to life inadequately by professional palaeontologists. Among extinct animals, the dinosaurs have stolen most of the limelight, and much of the rich store of research-level information about mammalian evolution reaches the public only as background material to the latest discoveries of rival anthropologists. Although there is a great story to tell about mammalian evolution, and a great opportunity to discuss how the scientific method can be applied to the subject, the good books on mammalian evolution over geological time have long been out of print or are badly outdated. Palaeontologists are bombarded by requests about the appearance in life of extinct mammals, and how they changed with time, but we possess few attempted reconstructions to show to the public; those that we do have are generally clones of previous attempts. Although professionals sometimes wince at reconstructions of fur colour patterns and other indefensible extrapolations from what is actually preserved in the fossil record, such images are undeniably useful for non-specialists. Life is breathed into the subject.

In this book, Michael Long (artist) and R. J. G. Savage (palaeontologist) do bring

\section{Edges of knowledge} their poorly known beginnings in the Mesozoic to the richly known record of the Cenozoic. The book combines evocative restorations with spritely text. Many of the illustrations are new and plausible reconstructions of unfamiliar beasts; others clearly owe a debt to previous renderings. Some are outrageously funny, such as the human-faced Thylacosmilus nicki, or the contrite Gigantopithecus and wistful Lystrosaurus. The text is well written and pitched at the right level to maintain interest, mixing solid information with interesting references and speculation. It starts with a quotation from Shelley's Prometheus Unbound and ends with Dale Russell's silly illustration of a hypothetical ET-like "dinosauroid hominid". Between these there is much food for thought for non-specialists. There are a number of minor errors, but these can be weeded out for the future editions that will surely follow.

Our understanding of mammalian evolution is itself evolving, as more complete specimens are found and, perhaps more importantly, as methods of analysis improve. Although I found the book rewarding, one criticism is that the authors have missed the chance to move up from Kiplingesque scenarios to epistemologically more mature ground. After all, the British Museum (Natural History) is leading the way in injecting scientific method into its exhibits about evolution. To complement that effort, the book could have moved from exciting animals to greater emphasis on exciting problems.

Malcolm C. McKenna is Frick Curator in the Department of Vertebrate Paleontology, American Museum of Natural History, New York, New York 10024, USA.

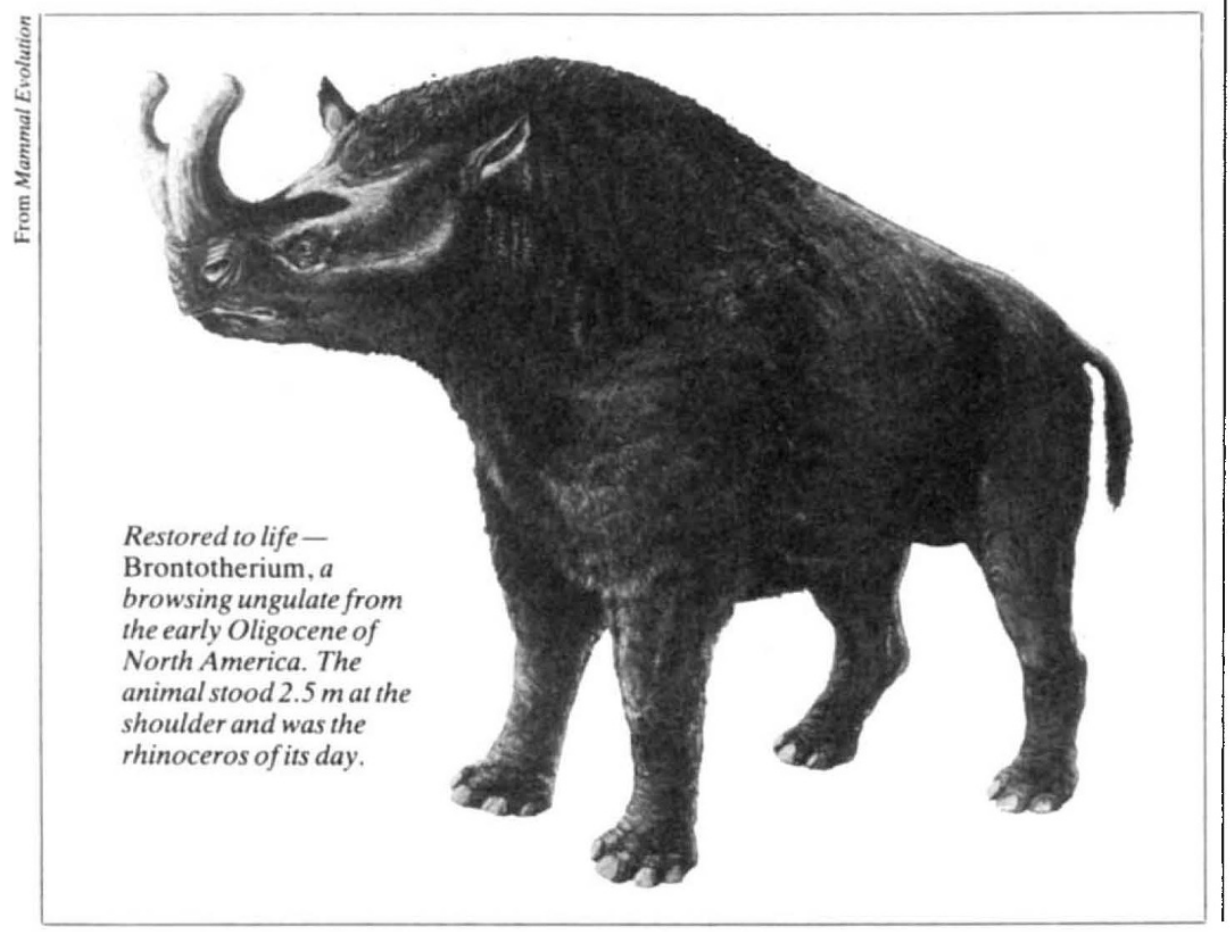

\section{A. Hallam}

Controversy in Victorian Geology: The Cambrian-Silurian Dispute. By James A. Secord. Princeton University Press:1986. Pp.363. \$49.50, £33.10.

Though geologists for the most part do not exhibit much interest in the history of their subject, there are few, in Britain at least, who do not know a little about the battle of those nineteenth-century giants Adam Sedgwick and Roderick Murchison. What had begun in friendly collaboration gradually developed over a quarter of a century into a bitter feud resulting in mutual estrangement. Like many stories known only in outline, however, the Cambrian-Silurian controversy is surrounded by misconceptions or is not properly appreciated for its most essential characteristic: it was a debate about the proper way to conduct a particular type of science, rather than a mere territorial or priority dispute. With an abundance of letters, notebooks and accounts of meetings available for study, the subject has long been ripe for the sort of book that Secord has written, a detailed, scholarly analysis using modern insights into the sociology of Victorian science.

Through the application of the novel technique of correlating strata by fossils, by the early 1830 s great strides had been made in establishing both a relative timescale and producing a reliable geological map for the structurally uncomplicated younger rocks in Britain. The ancient "grauwacke" or transition rocks of Wales, however, were a geological terra incognita that provided a kind of new frontier challenge. Sedgwick started work in North Wales and Murchison in the Welsh Borders, which led respectively to their proposing the Cambrian and Silurian systems, with a mutually agreed boundary being established. After some years it became apparent that Sedgwick's Upper Cambrian corresponded with Murchison's Lower Silurian. The newly created Geological Survey adopted Murchison's classification and Sedgwick became increasingly isolated. But the turning point came with the recognition of a major unconformity between Murchison's Lower and Upper Silurian, and the discovery of "primordial" fossils at a stratigraphic level well below that in which anything had previously been found. In the 1850 s and 1860 s many leading geologists switched their allegiance to a three-fold classification of what we now call the Lower Palaeozoic, and the dispute effectively came to an end in 1879 when Charles Lapworth proposed the term Ordovician for Murchison's Lower Silurian.

Secord argues that "Cambria" and 